\title{
KNOWLEDGE AND USES OF WILDLIFE IN THE COMMUNITY of Tetelpa, municipality of Zacatepec, Morelos, Mexico
}

\author{
Alejandro García-Flores ${ }^{1}$, Raúl Valle-Marquina ${ }^{1}$, José Manuel Pino-Moreno ${ }^{2 *}$, Rafael Monroy-Martínez ${ }^{1}$ \\ ${ }^{1}$ Centro de Investigaciones Biológicas, Universidad Autónoma del Estado de Morelos \\ ${ }^{2}$ Instituto de Biología, Universidad Nacional Autónoma de México \\ * Autorpara correspondencia:jpino@ib.unam.mx
}

Recebido em 24 de novembro de 2017. Aceito em 19 de dezembro de 2018. Publicado em 28 de dezembro de 2018.

\begin{abstract}
Aвstract - The objective of the research was to document and analyze the traditional knowledge and modes of use of the native fauna by the inhabitants of the community of Tetelpa, municipality of Zacatepec, Morelos. Several ethnozoological techniques, such as snowball sampling, were applied. Fifty semi-structured interviews were conducted, as well as guided visits to determine the animal species known to the community. Local informants recognize 37 species of wild vertebrates, $43 \%$ birds, $30 \%$ mammals, $22 \%$ reptiles and $5 \%$ amphibians. Of this total, $41 \%(\mathrm{n}=15)$ have food value, (11) have medicinal value, (7) are used as pets, (5) and ornamental (4). As shown by the value in use index, the species most used by the inhabitants is the rabbit Sylvilagus cunicularius (0.8). In three zones, the most important catch strategy involved the use of firearms, such as the shotgun or the "mound." Of the 37 species cited, 35\% (14) are considered harmful and interfere with the inhabitants' agriculture and livestock activities. When asked about the conservation status of native fauna, $92 \%$ of informants reported that there is a decrease in animal populations due to deforestation and commercial hunting. We conclude that the inhabitants of the community of Tetelpa have and preserve the traditional knowledge regarding native animals.
\end{abstract}

KEYWORDS: NATIVE FAUNA, USE VALUE, HUNTING, ETHNOZOOLOGICAL KNOWLEDGE.

\section{Conhecimento e uso da fauna na comunidade de Tetelpa, município de Zacatepec, México}

Resumo - O objetivo da investigação foi documentar e analisar o conhecimento tradicional e modos de uso da fauna nativa pelos moradores da comunidade de Tetelpa, município de Zacatepec, Morelos. Diversas técnicas etnozoológicas, como amostragem de bola de neve, foram aplicadas. Foram realizadas 50 entrevistas semi-estruturadas, bem como visitas guiadas para determinar as espécies animais conhecidas pela comunidade. Os informantes locais reconhecem 37 espécies de vertebrados selvagens, sendo $43 \%$ aves, $30 \%$ mamíferos, $22 \%$ répteis e $5 \%$ anfíbios. Deste total, $41 \%(\mathrm{n}=15)$ têm valor alimentar, (11) têm valor medicinal, (7) são usados como animais de estimação, (5) e ornamentais (4). Conforme demonstrado pelo índice de valor de uso, a espécie mais utilizada pelos habitantes é o coelho Sylvilagus cunicularius (0.8). Em três zonas, a estratégia de captura mais importante envolveu o uso de armas de fogo, como a espingarda ou o "monte". Das 37 espécies citadas, 35\% (14) são consideradas prejudiciais e interferem na agricultura dos habitantes e nas atividades de criação de animais. Quando perguntados sobre o estado de conservação da fauna nativa, 92\% dos informantes relataram que há uma diminuição nas populações animais devido ao desmatamento e à caça comercial. Concluímos que os habitantes da comunidade de Tetelpa têm e preservam o conhecimento tradicional relativo aos animais nativos.

Palavras-chave: fauna nativa, valor de uso, caça, conhecimento etnozoológico. 


\section{Conocimiento y uso de la fauna en la comunidad de Tetelpa, municipio de Zacatepec, Mexico}

Resumen - El objetivo de la presente investigación fue documentar y analizar el conocimiento tradicional y los modos de uso de la fauna nativa en la comunidad de Tetelpa, municipio de Zacatepec, Morelos. Se aplicaron diversas técnicas etnozoológicas, como el muestreo de bola de nieve. Se realizaron 50 entrevistas semiestructuradas y visitas guiadas para determinar las especies animales conocidas por la comunidad. Los informantes locales reconocen 37 especies de vertebrados silvestres, siendo el 43\% de aves, el 30\% de mamíferos, el 22\% de reptiles y el 5\% de anfibios, entre los cuales el $41 \%$ ( $\mathrm{n}=$ 15.17) tienen valor alimenticio, (11) valor medicinal, (7) como mascotas (5) y ornamentales (4). Como lo muestra el índice de valor de uso, la especie más utilizada por los habitantes es el conejo Sylvilagus cunicularius (0.8). En tres zonas, la estrategia de captura más importante involucró el uso de armas de fuego como la escopeta o el "monte". Des estas 37 especies mencionadas el 35\% (14.0) se consideran dañinas e interfieren con la agricultura de los habitantes y las actividades de cría de animales. Cuando se les preguntó sobre el estado de conservación de la fauna nativa, el $92 \%$ de los informantes dijeron que hay una disminución en las poblaciones de la especie debido a la deforestación y a la caza comercial. Concluimos que los habitantes de la comunidad de Tetelpa tienen y preservan el conocimiento tradicional referente a los animales nativos.

Palabras clave: fauna nativa, valor de uso, caza, conocimiento etnozoológico.

\section{INTRODUCTION}

Wildlife plays an essential role in the subsistence of populations in the tropical regions of the world, because it has contributed to food security and income generation (Fa et al. 2003, Nasi et al. 2008). Particularly, the use of the fauna resource in Latin America represents a fundamental activity for populations in rural areas (Challenger 1998), specifically for indigenous and farmer groups, being the latter the main appropriators of wildlife (Ojasti and Dallmeier 2000). In the area, the use of wildlife is carried out through subsistence hunting and its use is diversified beyond the food, because it is also used as an ornament, pet animals, handcraft, like guardians, magicreligious, medicinal or as a sale produc (Ojasti, 1993, Fang et al. 1997, Guerra et al. 2010). The appropriation of fauna has been documented in diverse rural communities in countries such as Colombia, Ecuador, Bolivia (Tejada et al. 2006, Montecaleno and Calvachi, 2009, Pozo et al. 2014, Martínez et al. 2016), but particularly in Brazil, a country that has stood out in the ethnozoological scientific production (Alves et al. 2010), research mainly on the use of fauna in traditional medicine, ethnoentomology, ethno-ethology, hunting, ethnocarcinology, ethnoornitology, ethnotaxonomy, education and management, the use of animals for magical-religious purposes and cultural symbolism, ethnomastozoology, ethnoherpetology and ethnomalacology (Alves and Souto, 2011). In this South American country, wildlife is mainly used by indigenous groups for several purposes such as food, trade in live animals, clothing, tools, medicinal and magical religious use (Alves et al. 2010).

For Ojasti and Dallmeier (2000), wildlife are all non-domestic animals. The General Law of Ecological Balance and Protection for the Environment in Mexico (SEGOB 1996) wildlife is defined as "those wildlife species that subsist subject to those processes of natural selection and that live freely, including their lesser populations under man's control, and those domestic animals that become feral due to their abandonment, and therefore become susceptible to capture and appropriation". Within this definition all those native animal species, as well as all those species introduced into the country (exotics) are included.

Wildlife presents ethical, cultural, economy, recreational, ecological, educational and scientific values (Zamorano de Haro 2009), and is an important component of the structure and dynamic of ecosystems, with important functions such as energy flux and recycling of nutrients (Ojasti and Dallmeier 2000). Use and exploitation of wildlife has had an important paper in the social and economic development of the farming and indigenous communities in Mexico (Alcérreca et al. 1988, Pérez et al. 1996, Retana 2006), being since immemorial time a natural resource for the maintenance of material and cultural necessities (Retana et al. 2011). For the native 
communities, wildlife flesh is a source of food, and therefore the protein in their diet (Naranjo et al. 2004). Other values of wildlife documented in Mexico are the medicinal and ceremonial uses (Pérez et al. 1996, Monroy and García 2013). Diversity and use of Mexican wildlife have varied with time, and space in the diverse ethnic groups. At this time four principal values are given to wildlife: 1. Use, 2. Change, 3. Option and 4. Existence (Pérez et al. 1996). Number one refers to the direct and tangible value that the user of the animal resources obtains for survival (e.g. subsistence hunting), number two points at the commercial interchange or barter with live animals as pets, number three refers to the sum of alternatives, goods, uses and future services which are narrowly associated with the genetic potential of the Mexican fauna, number four is the intrinsic value, for the simple fact of being live animals as part of the natural and cultural Mexican heritage.

Notwithstanding the fact that wildlife represents an essential resource for diverse Mexican communities (different studies have pointed out the fact that it contributes between 60 and $70 \%$ of the protein consumed in rural and native communities) (INE 1997), socioeconomic problems exist in Mexico and Morelos, which favor urban growth, such as: overexploitation of resources, destruction of the natural wildlife habitat due to the introduction of new cultivation areas and grasslands, real estate constructions, etc., this situation explains the gradual demise of diversity, distribution and abundance of wildlife in Mexico and Latin America (Guerra et al. 2010). In this context, the object of this research was the analysis of the traditional knowledge, value of use and the perception the inhabitants conserve of the wild fauna of Tetelpa, Zacatepec, Morelos, Mexico.

\section{MATERIAL AND METHODS}

\section{Study Area}

The meaning of the word Tetelpa is "Over the rocks", the region was occupied by groups of Matlazinca and Ocuilteca origin, later conquered by the Olmec, who later became established in Xochicalco between $600 \mathrm{BC}$ and 950 AC (García 2009), today this municipality is occupied by the Nahua group (Anonymous 2017).

Tetelpa was chosen for this study as there is to be found one of the last relicts of the low deciduous forest ecosystem in southern Morelos, where the social movement against a series of projects of the real estate industry, promoted by the state government, endangering wildlife and the quality of life of the Nahua communities in southern Morelos is strong.

The study area belongs to the Municipality of Zacatepec, in the State of Morelos, Mexico, and has the neighboring municipalities of Puente de Ixtla, Jojutla, Tlaquiltenango and Tlaltizapán. Its geographical coordinates are 18390 0 N, and 9911 0" W (Figure1). The average height is of $920 \mathrm{~m}$ (INEGI 2010). The type of weather according to the system of Köppen, modified by García (1990) is Aw, (w)(i')g, meaning subhumid with summer rains, the driest of the subhumids, with dog-days, winter rain less than five, little oscillation. The average annual temperature is $22.0^{\circ} \mathrm{C}$, the annual average rainfall is between 800 and $1000 \mathrm{~mm}$. A short part of the Apatlaco River crosses the state, where the towns of Tetelpa, Zacatepec and Galeana use its waters for crops.

Next to the town of Tetelpa sits the State Park Cerro de la Tortuga (turtle hill), established on September 5, 2012, with a protected surface of 310.199 hectares. The type of vegetation of the area (Miranda and Hernández 1963) is low deciduous forest. Among the plants in the area are to be found Gliricidia sepium (Fabaceae) (matarrata), Ipomoea arborescents (Convolvulaceae) (casahuate), Mimosa polyantha (Fabaceae) (uña de gato), Amphipterygium adstringens (Anacardiaceae) (cuachalalate), Acacia farnesiana (Fabaceae) (huizache) and Acacia cocbliacantha (Fabaceae) (cuabata). This park has around 26 species of mammals, 50 of birds, three reptiles and two amphibians. 


\section{Etnozoological Methods}

The first phase of this research was to approach the local authorities to inform them of our study, and our methods of study and interests (Taylor and Bogdan 1987). They gave us the authorization to initiate the study of the community. In the field, we obtained the wanted information through different ethnozoologic techniques (Santos 2009), we utilized the "snowball" technique, consisting of choosing one person randomly, later this person was asked for the reference of another person that used wildlife, repeating this method on and on till no useful information was obtained (Salamanca and Martin 2007).

We used a Tascan Dr.-05 audio-digital recorder for our semi-structured interviews, with the consent of the collaborator. Questions asked were:

1.- Name, age,length of residence and occupation.

2.- Which species of wildlife were observed in the area.

3.- Common name of those animals he has used and how they were used.

4.- Instruments used to hunt wildlife and places where he found them.

5.-Are wild animals commercialized.

6.-Species considered harmful.

7.- Species which have legends, myths or beliefs.

8.- Perception on the abundance of wildlife in the area.

A priori and during the interviews we had support literature for the identification of the species (Urbina and Morales 1994, Peterson and Chalif 1998, Aranda 2000, Aguilar et al. 2003, Castro et al. 2006, Aranda 2012).

Later we walked the area with local guides to observe those species referred to in the interviews. In the field these animals were identified through direct observations and with a photographic catalog, which was ratified by various taxonomy specialists and indirectly with the recording of footprints and excreta (Monroy and García 2013). For each species, it was investigated its conservational status through the IUCN (2016).

For each species we calculated the Value Index (Alves et al. 2010) with the following formula:

$\mathrm{IVU}=\sum \mathrm{U} / \mathrm{n}$

Where

IVU $=$ value index of species use,

$\sum=$ summation

$\mathrm{U}=$ number of citations per species]

and $\mathrm{n}=$ number of interviewed persons

\section{RESUlTS AND DISCUSSION}

Those people interviewed were chosen per Cotton (1996), who mentions three factors to consider trusty interviewees: number of native interviewees, time of residence of those non-natives, and the average age. 50 interviews were applied to men of the community, between December 2014 to December 2015.

Of the total people interviewed, $82 \%(n=41)$ are native to Tetelpa, the rest $(18 \%)(n=9)$ have resided there between 16 and 55 years. The average age of the informers is 57 years: in general, the age of the informers is between 28 and 88 years, $62 \%(n=31)$ are farmers or agricultural workers, while $28 \%(n=14)$ have different activities such as workers or teachers, and $10 \%(n=5)$ were bricklayers. 
Contreras et al. (2004) have reported in the State of Morelos, 101 mammal species, 370 bird species, 79 reptile species and 24 amphibians. In our paper the interviewers recognize 37 wild vertebrates, 16 of which are birds, 11 mammals, eight reptiles and two amphibians (Table 1).

Numbers which represent $6.4 \%$ of those species reported for this state, and $45 \%$ of those reported by the Secretaría de Desarrollo Sustentable (2012), for the Tortuga Hill State Park (Parque Estatal Cerro de la Tortuga), four endangered wildlife species are reported for the municipality, one seriously endangered, and one in special protection.

\section{Use of Wildlife}

$100 \%$ of those interviewed recounted having used or using some species of wildlife. Of the 37 species recognized by the informers in the study area, $40.5 \%(\mathrm{n}=15)$, have usage value (Table 2), $40 \%$ are mammals $(\mathrm{n}=6)$, $33 \%$ are birds $(n=5), 20 \%$ are reptiles $(n=3)$ and $7 \%(n=1)$ are amphibians.

Comparatively García (2008) reported for two communities in the Reserva Estatal Sierra de Montenegro (State Reserve of Montenegro Sierra), under similar conditions of ecosystem, (low deciduous forest) and farmer population,105 wildlife species, of which 32 had usage value for the communities. In a quite different area, in southeastern Mexico, García (2012), in his publication on two communities in the Reserva de la Biosfera de la Encrucijada, in Chiapas, reported that the inhabitants know 104 species of wildlife, of which 44 are used as food, 12 for medicine and 9 are used as pets. While rural communities in the protected area of Chapada del Araripe, Brazil, there were 15 species of fauna with use value, representing $28 \%$ of the species mentioned in the area (Bonifacio et al. 2016). In the rural area of Caimito, Sucre, Colombia, the use of 42 species of wild fauna was recorded (De la Ossa-Lacayo and De la Ossa, 2012).

In this research, four usage values were reported, food, medicinal, ornamental and pets, which have been reported for the Sierra de Nanchititla, in the State of Mexico, where 33 species with five values of usage: food, ornament, medicinal, commercial and pets (Monroy et al. 2008). Monroy and García (2013) reported for the community of Xoxocotla, Morelos, Mexico, 23 wild vertebrates with five uses: food, medicine, pets, decoration and good-luck charms. Velarde and Cruz (2015) studying the communities of El Limon, Los Sauces and Chimalacatlan, in the Reserva de la Biosfera Sierra de Huautla, Morelos, Mexico, reported 16 species of animals used for food and medicine. On the other hand, Puc and Retana (2012) in their study of the town of Villa Guadalupe, Campeche, Mexico, registered 53 species of wildlife with eight use values: food, medicine, pet, mystic, commerce, ornamental, and hides, and as a tool. While Bonifacio et al. (2016) reported six categories of use among the food, artisan, medicinal, ornamental, mystic and other uses.

The Nahua inhabitants of the community of Tetelpa maintain the use of wildlife in force, even if the number of species and uses is less than in other studies, as the interviewee's wildlife represents a food resource for the farming families of the area.

The most important value for the inhabitants of Tetelpa is the food value, as they reported 12 species for it, representing $32 \%$ in the frequency of values. The most important species consumed are the rabbit, $(n=42)$, the black iguana ( $n=35)$, the armadillo $(n=24)$, the rattlesnake $(n=24)$, the opossum $(n=12)$, and the mourning dove $(\mathrm{n}=11)$. Other species used as food, rabbit, armadillo, the coati, black iguana, mourning dove, "huilota", quail and white-wing dove have also been reported by Velarde and Cruz (2015), in communities of the Reserva de la Biosfera de Huautla, Morelos. García (2012) reports for two communities in the Reserva de la Biosfera de la Encrucijada, in Chiapas, 44 species used as food. García et al. (2014), in the northern part of Morelos, in the Parque Nacional el Tepozteco, reported of the opossum, the armadillo and the coati used as food by the inhabitants of the area. 
Rodas et al. (2014) and Plata (2012) mention the armadillo, the opossum and the coati used as food by the inhabitants of the municipality of Copainala in Chiapas, Mexico. In the same area of southern Mexico, in Yucatan, Segovia et al. (2010) mention that the white-wing dove is the bird used most as food by the inhabitants of the whole state. The part most used is the meat, prepared in dishes as adobo or roasted, birds obtained as subsistence hunting. This usage value the most important form of use of wildlife in Latin America for its protein value, consisting of an alternative of animal protein to compliment the food intake of the rural population (Pérez and Ojasti 1996, Matallana et al. 2011, Restrepo 2012). In Tetelpa, another important category is the medicinal one, where seven species are known, making $19 \%$ of the total. The species most mentioned with this use are the black iguana $(n=35)$, the rattlesnake $(n=20)$, the skunk $(n=18)$, and the turkey vulture $(n=16)$. As an example, the black iguana is used to cure anemia, where the patient drinks its blood or eats the meat. This medicinal property was also mentioned by Reyna et al. (2015), in the communities of Ticuman in Tlaltizapan, Morelos. The flesh of the rattlesnake and the turkey vulture are used to cure cancer, the flesh of the armadillo and the skunk and opossum are used to cure pimples on the skin. The fat of the coyote is used for muscle pains and arthritis, the use of these animals is registered in the communities of Los Sauces, El Limon and Chimalacatlan, in the Reserve of the biosphere of Sierra de Huautla, Morelos (Velarde and Cruz 2015) and by the inhabitants of the Parque Natural Sierra de Nanchititla, in the State of Mexico (Monroy et al. 2008). In the Altos in Chiapas, the skin of the opossum is used for pimples on the skin instead of consuming its meat. In the present study species such as the skunk and the opossum that have been used since prehispanic times in the traditional Mexican medicine, which proves the effectivity and persistence that the use of animals have for the treatment of diseases (Enríquez et al. 2006). In a community of the Brazilian Amazon, 31 species of medicinal animals were registered, which treated health problems related to snake bites, pneumonia, asthma, indigestion, rheumatism, earache and bleeding (Barros et al. 2012), In communities near the San Guillermo Biosphere Reserve, San Juan, Argentina, the use of seven species of fauna were registered for medicinal purposes, mainly to treat disorders of the nervous and respiratory systems with the use of structures such as fat, lower extremities, bezoar stone, stomachs, feathers, flesh, blood, feces, wool and liver, while in the Northwest Puna of Argentina the medicinal use of 22 species of fauna were registered (Barbaran, 2004).The ornamental value represents $11 \%$, while the use for pets is $14 \%$, with four and five species each. The frequencies mentioned for the animals as ornamental were the rattlesnake $(n=9)$, the rabbit $(n=5)$, the river turtle ( $\mathrm{n}=5$ ), and the Dasypus by García (2008), Monroy et al. (2008), Monroy and García (2013), and Reyna et al. (2015). These species offer different structures such as skin (Rattlesnake), legs (rabbit), shells (armadillos) and river turtles which the Nahua inhabitants of Tetela use as personal ornament or for their homes. These ornaments are obtained secondarily, after the flesh of the animal has been consumed.

The category of pet is constituted by the rabbit $(n=13)$, the turtle $(n=8)$, the white-winged dove ( $n=3)$, the frog $(n=4)$, the black iguana $(n=1)$, animals which are sometimes captured to keep at home. For example, diverse research done in Morelos, it has been reported that the black iguana is a species widely used as a pet in some communities of the Reserva Estatal Sierra Montenegro (García 2008, Reyna 2013 and Reyna et al. 2015).

Those species with most use were the rabbit 0.8 , the iguana 0.7 , the rattlesnake 0.5 , and the armadillo 0.5 (Table 2). These four species must be considered in the promotion of rational, participative management plans, especially for the black iguana and the rattlesnake, as both fall into the endangered category of the Norma Oficial Mexicana-059-SEMARNAT-2010. The other species have a lesser value.

The group of wildlife that has the highest number of species with use is the group of mammals, as reported in other publications (Monroy et al. 2008, Hernández et al. 2013, Monroy y García 2013, Lira 2014). Asked for the reason for the preference of this group of animals, the interviewed persons commented that they are bigger, thus more meat, compared to the other groups of vertebrates (Monroy et al. 2008). 


\section{Hunting instruments and localities}

The principal instrument utilized is the firearm, mentioned in $100 \%$ of the interviewed people, , which it has also been documented in Brazil by Alves et al. (2009) and Hanazaki et al. (2009), but also, in different states of Mexico (Oaxaca, San Luis Potosi, Sinaloa, Tabasco, and Zacatecas), and in different cultural groups, for example in the Potosino-Zacatecano Highlands (Mellinket al. 1986), the Lacandones (March 1987), Zapotec, Chatinos and Chontales (Nahmad 1994), farmers of the coffee plantations of Veracruz (Tlapaya and Gallina 2010), Mayos and Yoremes in northern Sinaloa (Medina et al. 2013), and those in the Cañón del Usumacinta in Tabasco (Hernández et al. 2013). Other instruments used are the slingshot $26 \%(n=13)$, and $12 \%$ mentioned the use of dogs for the capture of wildlife.

Our information led us to three places within the community where wildlife is hunted: the bush, croplands and river sides. Three situations where the interviewed persons use the hunted animals are: 1 . For food, the few resources they have are not enough to purchase protein, 2 . When in need of medicinal care, as there are no resources for medical attention or medicine, and they consider that animal medicine is more effective, 3 . When they have a whim to consume wild meat. In this context, the hunting of game has little impact on the populations of wildlife, as this game is destined to feed the farmer's families, as well as to better the health of them (Naranjo et al. 2004).

\section{Perception of wildlife}

Eighteen percent of those species recognized by the persons interviewed are mentioned in myths or legends, which have been transmitted from generation to generation. Good examples are the indigo snake, the Gila monster and the owl. According to legend, this big, black snake looks for mothers that are suckling their babes, push the baby away, and suckle away, leaving baby without nourishment. To scare them away, people leave a "machete" and a hat outside their home Casas (2000), this legend is very common in Mexico. Reyna et al. (2015) mentions this belief as the most common tale told in the areas of the communities of Ticuman and Barranca Honda, in Tlaltizapan, Morelos. The Gila monster is known to be poisonous, to find it is bad luck, and you better leave it alone. The owl is believed to carry bad luck, legend well marked in Mexican culture, belief from prehispanic times (Reséndiz 2015). The interviewed people believe that when the owl sings, somebody is going to die. It is not supposed to be killed, or someone of your family will die. It is just scared away.

All snakes are killed indiscriminately (only six of the interviewed people say they do not kill the animal, but do take them to some far-away place). Rattlesnakes are very much feared, and are immediately killed. Casas (2000) published information about snakes and says that these animals are the group of vertebrates with the highest number of myths and legends, as well as fables, from snakes that suckle from cows and women, that all snakes are poisonous, and some that when they meet a human, follow him at full speed, lashing or whipping their backs. Freiberg (1970) mentions that snakes have been victims of a "satanization" by humans and have been persecuted and exterminated, causing a strong drop in their populations. Certain zoocultural manifestations such as these could be dangerous for the maintenance of natural populations (Masso 2006). For this reason, it is important to create participative programs of environmental culture to inform the communities of the ecological and social importance of all snakes. The information we have of myths and legends of these animals contributes to the protection of wildlife species such as the Gila monster and the "cacuana", being already protected animals by law.

Some informants believe that there is "harmful" wildlife, as reported by Elias and Valencia (1984) for Latin America and Castillo et al. (2016) in Colombia that damage crops. Birds considered "harmful" are Mourning dove, "Tijolo", Cowboy bird, Grackle, White-Fronted Parrot, White-Winged Dove, all causing damage to the corn crops (Zea mays) and rice (Oryza sativa). Among the mammals called "pests" are the rabbit, the coati, the oposs 
um, the house mouse and the ground squirrel. Villar (2000), says the major pest vertebrates in crops in Mexico are mice and rats, pocket gophers, squirrels, birds and rabbits. The same author lists those vertebrate pests of Morelos: the house mouse attacks corn, sugar cane and sorghum, parrots eat principally rice, and rabbits usually corn. Interviewed natives of Tetela identified some "pests", but said they don't especially go after them, as the damage they make is small, and scare them away, understanding the importance they have for them, some of them even helping to clear the "pests" in the crops, clean the land of dead animals, help pollination and people even see ornament in the field with these animals. "It is good that some animals be in the field, so I can come and show my children".

This means that the inhabitants recognize some services that wildlife does for them (Monroy and García 2013). The only species that is not tolerated is the ground squirrel, as it feeds on pumpkin, corn, peanuts, watermelon and beans.

Another productive activity affected by wildlife is animal husbandry, the coyote and the gray fox feed on chickens and turkeys. Interviewed natives said that in the past they had serious trouble with these predators, but the problem is very much diminished. Amador et al. (2013) mention that the gray fox consumes principally chickens and turkeys in southeastern Mexico, Peña and Castillo (2013) report the same eating habits for the gray fox in northeastern Mexico. It would be necessary that a series of participative actions on the management of these birds and inform the assistants how important for the environment these predators are, as the other prey of these predators are smaller animals that can be deleterious to cops, such as rodents and rabbits, as mentioned by Aranda et al. (1995).

Of those locals interviewed, $92 \%(\mathrm{n}=46)$ consider in a general way, that the abundance of wildlife is dropping, but $8 \%(n=4)$ consider it stable. This sad situation is exemplified by the white-tailed deer, that according to Escamilla et al. (2000), those elderly interviewed, was common in past years, and was the preferred mammal to be hunted, due to the larger amount of meat. According to those younger interviewed, this animal can not be found anymore, due to the fragmentation of its habitat, and even reaching a total absence in the place, due to the excessive illegal hunting, or has been pushed out due to other human activities, such as cattle raising, commercial agriculture and human encroachment.

Another reason people interviewed mention is commercial hunting by people outside of the community and the excessive use of different chemicals for agriculture. Contreras et al. (2004) mention that commercial agriculture and cattle-raising are activities that lead to the destruction of the environment, and reduce the number of refugia and food sources for different species of animals, therefore the reduction of their populations. It has been documented that the excessive use of non-specific chemicals in agriculture have had extensive damage on the fauna of wildlife (Sánchez 2000). Decarre and Bernardos (2012) mention the necessity of monitoring the use of agrochemicals used to control pests, as these products act not only upon them, but also on other organisms that can benefit the producers and their crops, such as arthropods, amphibians, reptiles, birds and mammals, and their use must be regulated by the municipal health authorities, and must plan for alternative rational use of the fauna called "pests".

\section{CoNCLUSION}

The results of the interviews the actual traditional knowledge of wildlife can be seen in the recognition of 37 species that exist in the study community, 15 of which have value as use, six are mammals, five are birds, three are reptiles and one is an amphibian. These species are principally used as food and for the treatment of diverse diseases. Those animals with a wide use are the rabbit, the black iguana, the rattlesnake and the armadillo. Here we suggest the establishment of management units for the observation of wildlife (communal breeding grounds), which permit the integral management of the species. The use of wildlife is for subsistence, but it is necessary to 
do population ecology studies with those groups of wildlife of the area to know the situation of the them, as the traditional knowledge of the inhabitants state that species are becoming scarce, including the white -tailed deer's elimination, and considering the necessities and the participation of the inhabitants (Mandujano 2004, 2010), the following actions are proposed: ecological restoration, zoning and territorial ordering of the community of the "ejido" (communal land) of Tetelpa, communal vigilance and environmental programs especially if we consider that, according to the inhabitants, the white-tailed deer has not been observed and that endangered and threatened species are also reported. Adding up, this type of ethnozoological studies, are important to know the different aspects of the use of the faunal resources by the Nahua community, such as the taxonomy of the animals, capture methods, reasons for the usage, as the systematized ethnozoological knowledge gives us elements susceptible to be integrated in the public conservation policies and rational management of wildlife for the benefit of those studied community.

\section{AcKNOWLedgments}

We thank Dr. Eraldo Medeiros Costa-Neto for his help in translating the summary into Portuguese and to Mr. Noe Castillo Torres for the help provided in the field. To the inhabitants of Tetelpa for their valuable time and their traditional knowledge of wildlife of their territory.

\section{References Cited}

Aguilar R. Dorado O. Arias MD. Alcázar H. and Castro R. 2003. Anfibios y reptiles de la sierra de Huautla, Estado de Morelos. Comisión Nacional para el Conocimiento y uso de la Biodiversidad. Universidad Autónoma del Estado de Morelos, México, CONABIO, 32 p.

Alcérreca C. Consejo JJ. Flores O. Gutiérrez D. Hentschel E. Herzig M. Pérez-Gil R. Reyes JM and Sánchez CV. 1988. Fauna silvestre y áreas naturales protegidas. México: Universo Veintiuno, 193 p.

Alves BJA. Azevedo NV. and Nóbrega ARR. 2010. Aspectos da caça e comércio ilegal da avifauna silvestre por populações tradicionais do semi-árido paraibano. Revista de Biologia e Ciências da Terra,10(2):39-49.

Alves RML. Confessor MVW. and Lopez L. 2009. Hunting strategies used in the semi-arid region of northeastern Brazil. Journal of Ethnobiology and Ethnomedicine, 5(12): 1-16.

Alves RNR and Souto MSWW. 2011. Ethnozoology in Brazil: current status and perspectives. Journal of Ethnobiology and Ethnomedicine, 7(22):1-19.

Amador AS. Naranjo EJ. and Jiménez FG. 2013. Wildlife predation on livestock and poultry: implications for predator conservation in the rainforest of south-east Mexico. Oryx, 47:243-250.

Anonymous 2017. Nahuas.Availableat:https://es.wikipedia.org/wiki/Nahuas.

Aranda SJM. 2000. Huellas y otros rastros de mamíferos grandes y medianos de México. México:Instituto de Ecología. Xalapa,Comisión Nacional para el Conocimiento y Uso de la Biodiversidad (CONABIO), 212 p.

Aranda SJM. 2012. Manual para el rastreo de mamíferos silvestres de México.México: CONABIO, 255 p. 
Aranda M. López RN. and López de Buen L. 1995. Hábitos alimentarios del coyote (Canis latrans) en la Sierra del Ajusco, México. Acta Zoológica, 65:89-99.

Barbarán FR. 2004. Usos mágicos, medicinales y rituales de la fauna en la Puna del Noroeste Argentino y Sur de Bolivia. Contribuciones al Manejo de Vida Silvestre en Latinoamérica 1:1-26.

Barros BF. Varela AMS. Pereira MH. and Vicente L. 2012. Medicinal use of fauna by a traditional community in the Brazilian Amazonia. Journal of Ethnobiology and Ethnomedicine, 8:37.

Bonifácio MKK. Schiavetti, A. and Xavier FEM. 2016. Fauna used by rural communities surrounding the protected area of Chapada do Araripe, Brazil. Journal of Ethnobiology and Ethnomedicine,12:41.

Casas AG. 2000. Mitos, leyendas y realidades de los reptiles en México. Ciencia Ergo Sum, 7 (3):286-291.

Castillo I. Rodríguez A. Montes R. and González D. 2016. Fauna silvestre que afecta los cultivos en Boyacá y control del daño a cultivos de maíz. Revista Ciencia y Agricultura 14 (1): 75-84.

Castro FR, Vergara GG, Bustos Z MG, and Arizmendi MW. 2006. Diversidad y distribución de anfibios del estado de Morelos, México. Acta Zoológica Mexicana 22(1):95-101.

Challenger, A. 1998. Utilización y conservación de los ecosistemas terrestres de México: Pasado, presente y futuro. México, D.F.: UNAM Instituto de Biología.

Contreras MT. Boyas JC. and Jaramillo MF. 2004. La Diversidad Biológica en Morelos: Estudio del Estado. México: CONABIO y Universidad Autónoma del Estado de Morelos, 156 p.

Cotton MC. 1996. Ethnobotany: Principles and Applications. RU:Wiley. Chichester,434 p.

Decarre J. and Bernardos J. 2012. Monitoreo de uso de agroquímicos, evaluación de riesgo ecotoxicologico. Argentina Buenos Aires: Instituto Nacional de Tecnología Agropecuaria (INTA), 14 p.

De la Ossa-Lacayo A. and De la Ossa J. 2012. Utilización de fauna silvestre en el área rural de Caimito, Sucre, Colombia. Revista Colombiana de Ciencia Animal, 4(1):46-58.

Elías DJ. and Valencia D. 1984. La agricultura latinoamericana y los vertebrados plagas. Interciencia, 9(4): 223-229.

Enríquez VP. Mariaca MR. Retana GOG. and Naranjo PEJ. 2006. Uso medicinal de la fauna silvestre en los Altos de Chiapas, México. Interciencia, 31(7):491-499.

Escamilla A. Sanvicente M, Sosa M. and Galindo LC. 2000. Habitat Mosaic, Wildlife Availability, and Hunting in the Tropical Forest of Calakmul, México. Conservation Biology, 14:1592-1601.

Fa J. Dominic E. and Meeuwig J. 2003. Bushmeat and Food Security in the Congo Basin: Linkages between Wildlife and People's Future. Environmental Conservation, 30 (1): 71-78.

Fang TG. Bodmer RE. Aquino R. and Valqui MH. Eds. 1997. Manejo de la fauna silvestre la Amazonia, Editorial Siglo XXI, México D. F.

Freiberg M. 1970. E1 mundo de los ofidios. Argentina: Albatros, 152 p. 
García E. 1990. Climas, 1:4000 000. IV.4.10 (A). Atlas Nacional de México. Vol. II. México: Instituto de Geografía, Universidad Nacional Autónoma de México, 90 p.

García FA. 2008. La etnozoología como una alternativa para el desarrollo comunitario sustentable en la Reserva Estatal Sierra de Monte Negro, Morelos, México. Master’s thesis. México: UAEM, 225 p.

García FA, Lozano GMA. Ortiz VAL. and Monroy MR. 2014. Uso de mamíferos silvestres por los habitantes del Parque Nacional El Tepozteco, Morelos, México. Etnobiología, 12 (3):57-67.

García MJ. 2009. Inventario del archivo del museo comunitario San Esteban Tetelpan, Zacatepec, Morelos. México: Apoyo al desarrollo de archivos y bibliotecas de México, A.C., 22 p.

García BS. 2012. Conocimiento y usos tradicionales de la fauna en dos comunidades campesinas de la Reserva de Biosfera de la Encrucijada, Chiapas. Etnobiología, 11 (1):16-28.

Guerra RM. Calme S. Gallina TS. and Naranjo PE. 2010. Uso y Manejo de la Fauna Silvestre en el Norte de Mesoamérica. México: Secretaria de Educación, Gobierno del Estado de Veracruz, Xalapa, Veracruz, 459 p.

Hanazaki N. Alves, R. and Begossi A. 2009. Hunting and use of terrestrial fauna used by Caiçaras from the Atlantic Forest coast (Brazil). Journal of Ethnobiology and Ethnomedicine, 5:36.

Hernández LA, Rodríguez RA. and Aquino BV. 2013. Diagnostico en el uso de la fauna, en el área de protección de flora y fauna "Cañón del Usumacinta" Tenosique, Tabasco. Ra Ximhai 9 (1):1-13.

Hernández J. Campos C. and Borghi C. 2015. Medicinal use of wild fauna by mestizo communities living near San Guillermo Biosphere Reserve (San Juan, Argentina). Journal of Ethnobiology and Ethnomedicine, 11:15

INE (Instituto Nacional de Estadística) 1997. La valuación económica de la biodiversidad en México. Dirección de Economía Ambiental. CONABIO. Available at:http://www2.inecc.gob.mx/publicaciones/gacetas/163/valuacion.htl

INEGI (Instituto Nacional de Estadística y Geografía) 2010. Censo de Población y Vivienda. Available at: http://www. censo2010.org.mx/

International Union for Conservation of Nature (IUCN). 2018. Red List Threatened Species. Recuperado de https:// www.iucnredlist.org/

Lira TI. Briones SM. Gómez FR. Ojeda de ARD. and Peláez AA. 2014.Uso y aprovechamiento de la fauna silvestre en la Selva Zoque, México. Acta Zoológica Mexicana, 30 (1):74-90.

Mandujano RS. 2004. Análisis bibliográfico de los estudios de venados en México. Acta Zoológica Mexicana, 20:211-251.

Mandujano RS. 2010. Potencial del bosque tropical seco para la producción de venado cola blanca (Odocoileus virginianus) en México. In: O. Villareal EB. et al. (Eds.), Conservación y manejo de fauna cinegética en México Vol. II. México: Benemérita Universidad Autónoma de Puebla, Puebla, p. 101-130.

March MIJ. 1987. Los Lacandones de México y su relación con los mamíferos silvestres: un estudio etnozoológico. Biótica, $12(1): 43-56$. 
Martínez SMP. López AHF. and Sánchez PP. 2016. Cacería de subsistencia de mamíferos en el sector oriental de la reserva de biosfera el Tuparro, Vichada (Colombia). Acta Biológica Colombiana, 21(1), 151-166.

Masso GE. 2006. La identidad cultural como patrimonio inmaterial: relaciones dialécticas con el desarrollo. Theoria,15 (1):89-99.

Matallana C. Lasso C. and Baptiste M. 2011. Carne de Monte y Consumo de Fauna Silvestre en la Orinoquia y Amazonia (Colombia y Venezuela). Instituto de Investigación de Recursos Biológicos Alexander von Humboldt: Colombia.

Medina SM. Sandoval EA. Lara E. Piña H. Martínez R. and Rojo GE. 2013. Etnozoología del pueblo Mayo-Yoreme en el norte de Sinaloa: uso de vertebrados silvestres. Revista de Agricultura, Sociedad y Desarrollo, 10 (3): 335-358.

Mellink BE. Aguirre RJR. and García ME. 1986. Utilización de la Fauna Silvestre en el Altiplano Potosino-Zacatecano. Colegio de Postgraduados, Centro Regional para Estudios de Zonas Áridas y Semiáridas. México, D.F.

Miranda F. and Hernández XE. 1963. Los tipos de vegetación de México y su Clasificación. Boletín de la Sociedad Botánica de México, 28:29-179.

Monroy MR. and García FA. 2013. La fauna silvestre con valor de uso en los huertos frutícolas tradicionales de la comunidad indígena de Xoxocotla, Morelos, México. Etnobiología, 11 (1): 44-52.

Monroy VO. Cabrera L. Suárez P. Zarco GMM. Rodríguez SC. and Urios V. 2008. Uso tradicional de vertebrados silvestres en la Sierra Nanchititla, México. Interciencia, 33:308-313.

Moncaleano NMA. and Calvachi ZBA. 2009. Uso de la fauna silvestre del Lago de Tota: Peces, herpetos, aves y mamíferos. Ambiente y desarrollo, 13(25): 82-99.

Nahmad S. González A. and Vázquez MA. 1994. Medio ambiente y tecnologías indígenas en el sur de Oaxaca. México: Centro de Ecología y Desarrollo, 171 p.

Naranjo JE. Guerra MM. Bodmer ER. and Bolaños EJ. 2004. Subsistence hunting by three ethnic group of the Lacandon forest, Mexico. Journal of Ethnobiology, 24:233-253.

Norma Oficial Mexicana-059-SEMARNAT. 2010. Available at:http://www.profepa.gob.mx/innovaportal/file/435/1/ NOM_059_SEMARNAT.pdf

Nasi R. Brown D. Wilkie D. Bennett E. Tutin C. van Tol G. and Christophersen T. 2008. Conservation and use of wildlifebased resources: the bushmeat crisis. Technical Series No. 33. Bogor: Secretaría del Convenio sobre Diversidad Biológica, Montreal y el Centro para la Investigación Forestal Internacional (CIFOR).

Ojasti J. 1993. Utilización de fauna silvestre en América Latina, situación y perspectivas para un manejo sostenible. Roma: FAO.

Ojasti J. and Dallmeier F. 2000. Manejo de Fauna Silvestre Neotropical.Washington DC:SI/MAB Series \#5. Smithsonian Institution/MAB Biodiversity Program, 280 p.

Peña MJL. and Castillo A. 2013. Depredación de ganado por jaguar y otros carnívoros en el noreste de México. Therya, 4 (3):431-446. 
Pérez EM. And Ojasti J. 1996. La utilización de la fauna silvestre en la América tropical y recomendaciones para su manejo sustentable en las sabanas. Ecotrópicos, 9 (2):71-82.

Pérez GSR. Jaramillo MF. Muñiz SAM. and Torres GMG. 1996. Importancia económica de los vertebrados silvestres en México. Ed. CONABIO, PG7 Consultores 170 p.

Peterson TR. and Chalif LE. 1998. Aves de México. Guía de campo de todas las especies encontradas en México. México: Diana, $473 \mathrm{p}$.

Pozo, RWE. Cárdenas TCD. Dávila GL. And Eras MA. 2014. Conservación y aprovechamiento de la ornitofauna y flora presente en bosques riparios en los Tsáchilas, Ecuador. Memorias del VI Congreso Forestal Latinoamericano. México.

Puc GRA. and Retana GOG. 2012. Uso de la fauna silvestre en la comunidad maya Villa de Guadalupe, Campeche, México. Etnobiología, 10 (2):1-11.

Plata A. 2012. Importancia de la fauna silvestre en la etnia Sikuani, comunidad de Cumarianae, selva de Matavén, Vichada, Colombia. Colombia Cátedra Ambiental citadina, una multiconstrucción para la Universidad Colombiana. Volumen 1. Editorial Universidad Sergio Arboleda, Bogotá.

Reséndiz MJF. 2015. Los monolitos de Cuauhnahuac. La Jornada Morelos: suplemento cultural "E1 Tlacuache”. México. 4 p.

Restrepo CS. 2012. Carne de monte y seguridad alimentaria: Bases técnicas para una gestión integral en Colombia. Instituto de Investigación de Recursos Biológicos Alexander Von Humboldt: Colombia.

Retana GOG. 2006. Fauna Silvestre de México. Aspectos Históricos de su Gestión y Conservación. México: Ciencia y Tecnología. Fondo de Cultura Económica, 211 p.

Retana GOG. Aguilar NMS. and Niño GG. 2011. Uso de la vida silvestre y alternativas de manejo integral: el caso de la comunidad maya de Pich, en Campeche, México. Tropical and Subtropical Agroecosystems, 14:885-890.

Reyna RMA. 2013. Conocimiento etnoherpetológico en las comunidades de Barranca Honda y Ticumán, en la Reserva Estatal Sierra de Montenegro, Morelos, México. Tesis de Licenciatura. Universidad Autónoma del Estado de Morelos.

Reyna RMA. García FA. Neri CEE. Alagón CA. and Monroy MR. 2015. Conocimiento etnoherpetológico de dos comunidades aledañas a la Reserva Estatal Sierra de Montenegro, Morelos, México. Etnobiología, 13 (2):37-48.

Rodas J. Ocampo P. and Coutiño P. 2014. Uso de los mamíferos silvestres en el municipio de Copainalá, región Zoque, Chiapas, México. Quehacer Científico en Chiapas, 9:3-9.

Salamanca CAB. and Martin CBC. 2007. El diseño en la investigación cualitativa. Nure Investigación, 26:6.

Sánchez SS. 2000. Vertebrados silvestres registrados en una parcela de palma aceitera en Tabasco, México. ASD Oil Palm Papers, 20:17-18.

Santos RA. 2009. Metodologia de la investigación etnozoologica. In: EM Costa-Neto, D. Santos-Fita and M. Vargas-Clavijo (Coord.) Manual de etnozoología.Una guía teórico-práctica para investigar la interconexión del ser humano con los animales. España: Ediciones Tundra, p. 253-272. 
Secretaría de Desarrollo Sustentable. 2012. Parque Estatal “Cerro de la Tortuga”. Available at:http://sustentable.morelos. gob.mx/categoria/temas/anp/cerro-de-la-tortuga.

SEGOB (Secretaría de Gobernación) 1996. Ley General del Equilibrio Ecológico y la Protección al Ambiente. Diario Oficial de la Federación, 13 de diciembre de 1996.

Segovia CA. Chable JS. Delfin GH. Sosa EJ. and Hernández BSF. 2010. Aprovechamiento de fauna silvestre en comunidades mayas. In: Durán R. y M. Méndez. Biodiversidad y Desarrollo Humano en Yucatán. México: CICY, PPD-FMAM, CONABIO, SEDUMA. Mérida, Yucatán, pp. 385-387.

Taylor SJ. and Bogdan R. 1987. Introducción a los métodos cualitativos de investigación. Paidós. Barcelona, España.

Tejada R. Chao E. Gómez H. Painter L. and Wallace R. 2006. Evaluación sobre el uso de la fauna silvestre en la tierra comunitaria de origen, Tacana, Bolivia. Ecología en Bolivia, 41(2), 138-148.

Tlapaya L. and Gallina S. 2010. Cacería de mamíferos medianos en cafetales del centro de Veracruz, México. Acta Zoológica Mexicana, 26(2):259-277.

Urbina TF. and Morales G. 1994. Aves de Morelos de importancia económica y rapaces diurnas. México: Centro de Investigaciones Biológicas, Universidad Autónoma del Estado de Morelos, Secretaria de Educación Pública, 60 p.

Velarde ES. and Cruz LA. 2015. La fauna silvestre y su relación con el bienestar de tres comunidades de la Reserva de la Biosfera Sierra de Huautla, Morelos. Etnobiología, 13 (1): 39-52.

Villar GD. 2000. Principales vertebrados plaga en México: situación actual y alternativas para su manejo. Revista Chapingo Serie Ciencias Forestales y del Ambiente, 6 (1):41-54.

Zamorano de Haro P. 2009. La flora y la fauna silvestre en México y su regulación. Estudios Agrarios,15 (40): 159-167. 
Table 1. Species richness of wildlife recognized by the interviewers of the community of Tetelpa, Zacatepec, Morelos, Mexico, and their protection status.

\begin{tabular}{|c|c|c|c|}
\hline Order, family, genus and specie & Local name & Mexican official standard 059- 2010 & IUCN (2016) \\
\hline \multicolumn{4}{|l|}{ ANURA } \\
\hline \multicolumn{4}{|l|}{ Bufonidae } \\
\hline Rhinella marina & Toad & N.R. & L.C. \\
\hline \multicolumn{4}{|l|}{ Ranidae } \\
\hline Lithobates spectabilis & River frog & N.R. & L.C. \\
\hline \multicolumn{4}{|l|}{ SQUAMATA } \\
\hline \multicolumn{4}{|l|}{ Boidae } \\
\hline Boa constrictor imperator & "Mazacuata" & $\mathrm{T}$ & L.C. \\
\hline \multicolumn{4}{|l|}{ Viperidae } \\
\hline Crotalus culminatus & Rattlesnake & $\mathrm{T}$ & L.C. \\
\hline \multicolumn{4}{|l|}{ Colubridae } \\
\hline Drymarchon corais & Rat snake & N.R & \\
\hline Salvadora mexicana & & S.E. & L.C. \\
\hline \multicolumn{4}{|l|}{ Elapidae } \\
\hline Micrurus laticollaris & Coral snake & S.P & L.C. \\
\hline \multicolumn{4}{|l|}{ Iguanidae } \\
\hline Ctenosaura pectinata & Black iguana & $\mathrm{T}$ & \\
\hline \multicolumn{4}{|l|}{ Helodermatide } \\
\hline Heloderma horridum & Gila monster & $\mathrm{T}$ & L.C. \\
\hline \multicolumn{4}{|l|}{ TESTUDINES } \\
\hline \multicolumn{4}{|l|}{ Kinosternidae } \\
\hline Kinosternon integrum & Riverturtle & S.P. & $\mathrm{LC}$ \\
\hline \multicolumn{4}{|l|}{ COLUMBIFORMES } \\
\hline \multicolumn{4}{|l|}{ Columbidae } \\
\hline Zenaida asiatica & White wingeddove & N.R. & \\
\hline Columbina passerina & Mourningdove & N.R. & L.C. \\
\hline Zenaida macroura & "Huilota" & N.R. & L.C. \\
\hline \multicolumn{4}{|l|}{ GALLIFORMES } \\
\hline \multicolumn{4}{|l|}{ Odontophoridae } \\
\hline Phylortyx fasciatus & Quail & N.R. & \\
\hline \multicolumn{4}{|l|}{ Cracidae } \\
\hline Ortalis poliocephala & Chachalaca & N.R & L.C. \\
\hline \multicolumn{4}{|l|}{ CICONIFORMES } \\
\hline \multicolumn{4}{|l|}{ Ardeidae } \\
\hline Bubulcus ibis & Egret & N.R. & L.C. \\
\hline \multicolumn{4}{|l|}{ Cathartidae } \\
\hline Cathartes aura & Black of turkeyvultures & N.R. & L.C. \\
\hline \multicolumn{4}{|l|}{ CUCULIFORMES } \\
\hline \multicolumn{4}{|l|}{ Cuculidae } \\
\hline Piaya cayana & Cowboy bird & N.R. & L.C. \\
\hline Crotophaga sulcirostris & “Tijolo" & N.R. & L.C. \\
\hline \multicolumn{4}{|l|}{ PASERIFORMES } \\
\hline Icteridae & & & \\
\hline Quiscalus mexicanus & Grackle & N.R. & L.C. \\
\hline Turdidae & & & \\
\hline Turdus rufopalliatus & Robin & N.R. & L.C. \\
\hline Corvidae & & & \\
\hline Corvus corax & Crow & N.R. & L.C. \\
\hline
\end{tabular}




\section{Order, family, genus and specie Local name}

\section{Strigidae}

Glaucidium brasilianum

FALCONIFORMES

\section{Falconidae}

Caracara cheriway

PACIFORMES

\section{Picidae}

Picoides scalaris

Amazona sp.

LAGOMORPHA

Leporidae

Sylvilagus cunicularius

CINGULATA

\section{Dasypodidae}

Dasypus novemcinctus

CARNÍVORA

\section{Procyonidae}

Nasua narica

Procyon lotor

\section{Canidae}

Canis latrans

Urocyon cinereoargenteus

\section{Mephitidae}

Mephitis macroura

DIDELPHIMORPHIA

\section{Didelphidae}

Didelphis virginiana

RODENTIA

\section{Sciuridae}

Spermophilus variegatus

\section{Muridae}

Mus musculus

ARTIODACTYLA

\section{Cervidae}

Odocoileus virginianus

Parrot

Owl N.R.

Mexican official standard 059- 2010

IUCN (2016)

Cara-cara N.R.

Woodpecker N.R.

L.C.

N.R.

Rabbit N.R.

Armadillo N.R.

L.C.

Coati N.R.

L.C.

Raccoon N.R.

L.C.

Coyote N.R. I.R.

Gray Fox N.R. L.C.

$\begin{array}{lll}\text { Skunk N.R. } & \text { L.C. }\end{array}$

Opossum N.R. L.C.

Groundsquirrel N.R. L.C.

Mouse N.R L.C.

White taildeer N.R. L.C. 
Table 2. A taxonomic relation and uses of wildlife in the community of Tetelpa.

\begin{tabular}{lccc}
\hline SCIENTIFIC NAME & USES & USED PART & USE VALUE \\
\hline Lithobates spectabilis & Food, Pet & Meat, Whole animal & 0.1 \\
Crotalus culminatus & Medicinal, Ornamental & Meat, Skin & 0.5 \\
Ctenosaura pectinata & Food, Medicinal, Pet & Meat, Eggs, Blood & 0.7 \\
Kinosternon integrum & Food, Pet, Ornamental & Meat, Whole animal, Shell & 0.2 \\
Zenaida asiatica & Food, Pet & Meat, Whole animal & 0.2 \\
Columbia passerina & Food & Meat & 0.2 \\
Zenaida macroura & Food & Meat & 0.1 \\
Phylortyx fasciatus & Food & Meat & 0.1 \\
Cathartes aura & Medicinal & Meat & 0.3 \\
Sylvilagus cunicularius & Food, Pet, Ornamental & Meat, Whole animal, Foot & 0.8 \\
Dasypus novemcinctus & Food, Medicinal, Ornamental & Meat, Shell & 0.5 \\
Nasua narica & Food & Meat & 0.1 \\
Canis latrans & Medicinal & Meat & 0.1 \\
Mephitis macroura & Medicinal & Meat & 0.4 \\
Didelphis virginiana & Food, Medicinal & Meat & 0.2 \\
\hline
\end{tabular}

Figure 1. The community of Tetelpa, Zacatepec, Morelos, Mexico. (INEGI, 2010).

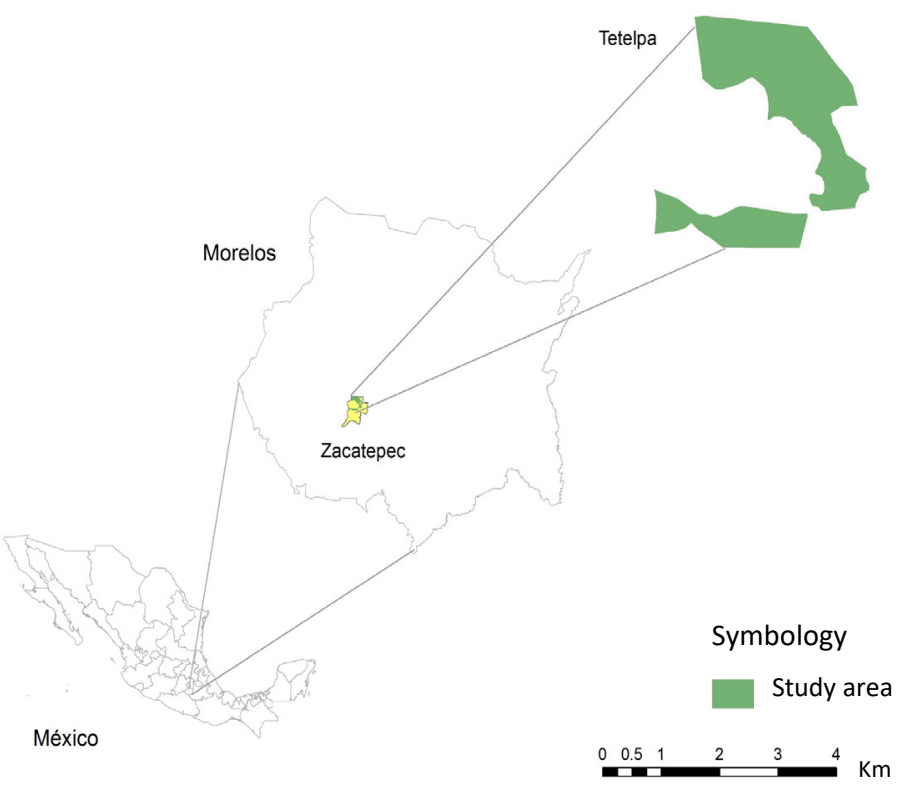

